\title{
Construction and transformation of social representations of AIDS and implications for health care
}

\author{
Denize Cristina de Oliveira ${ }^{1}$
}

Objectives: to analyze the process of the constitution and evolution of social representations and practices referent to aids, based on studies carried out in the last eleven years among health professionals. Method: a comparison of representational structures of aids in different decades was undertaken, accompanied by a study of the silent zone, involving health professionals. Data collection and analysis included techniques of free association, structural analysis, and study of the silent zone. Results: the existence of a process of change was observed in the social representations of aids, with the introduction of the possibility of co-existence with the disease and the reduction of the importance of death. Conclusions: this process is presented as the result of a complex movement of symbolic constructions arising from human interactions, contributing to knowledge of ways of thinking associated with the syndrome and to professional practices in healthcare.

Descriptors: Acquired Immunodeficiency Syndrome; Social Perception; Delivery of Health Care; Social Change.

${ }^{1}$ PhD, Full Professor, Faculdade de Enfermagem, Universidade do Estado do Rio de Janeiro, Brazil. 


\section{Construção e transformação das representações sociais da aids e implicações para os cuidados de saúde}

Objetivos: analisar o processo de constituição e evolução das representações e das práticas sociais relativas à aids, a partir de estudos desenvolvidos nos últimos onze anos, entre profissionais de saúde. Método: uma comparação de estruturas representacionais da aids em diferentes décadas, acompanhada de um estudo de zona muda foram realizados, envolvendo profissionais de saúde. A coleta e análise de dados englobaram as técnicas de evocações livres, análise estrutural e de estudo da zona muda. Resultados: observou-se a existência de um processo de mudança nas representações sociais da aids, com a introdução da possibilidade de convivência com a doença e a diminuição da importância da morte. Conclusões: esse processo apresenta-se como fruto de um complexo processo de construções simbólicas, oriundas das interações humanas, contribuindo para o conhecimento dos modos de pensar associados à síndrome e para as práticas profissionais em saúde.

Descritores: Síndrome de Imunodeficiência Adquirida; Percepção Social; Assistência à Saúde; Mudança Social.

\section{Construcción y transformación de las representaciones sociales del sida e implicaciones para los cuidados en salud}

Objetivos: Discutir la constitución y evolución de las representaciones y de las prácticas sociales relativas al sida, a partir de los estudios desarrollados en los últimos once años, entre profesionales de la salud. Métodos: Fue realizada una comparación de las estructuras representacionales del sida en diferentes décadas, acompañada de un estudio de zona muda, envolviendo profesionales de la salud. La recolecta y el análisis de los datos abarcó las técnicas de evocación libre, análisis estructural y estudio de zona muda. Resultados: Se observó la existencia de un proceso de cambio en las representaciones sociales del sida, con la introducción de la posibilidad de convivencia con la enfermedad y la disminución de la importancia de la muerte. Conclusiones: Este proceso se muestra como resultado de un proceso complejo de construcciones simbólicas que surgen de las interacciones humanas, lo que contribuye al conocimiento de las formas de pensamiento asociadas con el síndrome y las prácticas de los profesionales de la salud.

Descriptores: Síndrome de Inmunodeficiencia Adquirida; Percepción Social; Prestación de Atención de Salud; Cambio Social.

\section{Introduction}

Acquired Immunodeficiency Syndrome (AIDS*) and the Human Immunodeficiency Virus (HIV) appeared - at the beginning of the 80's in the United States of America, and in 1982 in Brazil - as a mysterious and terrorizing phenomena, given their characteristics of rapid lethality and extreme disfiguration of the body. This fact had an even greater impact due to their occurrence at a time when the war against infectious-parasitical diseases was considered won: diseases which, in the social imaginary, were destined for poor countries or regions - or to history books covering the distinct epidemics of the Western world.
After its identification in 1981 in the United States of America ${ }^{(1)}$, cases were reported similar to the new disease, without a specific clinical concept and with various titles which were loaded with moral aspects, such as Gay Pneumonia, Gay Cancer, Gay Syndrome or, even, Gay Related Immune Deficiency (GRID)(2).

The emaciation of cholera, the dangerousness of plague, the spread of cancer, and its relation with sexual transmission - bearing a resemblance to syphilis - encouraged, on the one hand, its anchoring in classifications considered scientific in known pathologies, while on the other hand permitting the activation 
of symbolisms available in the collective memory of common knowledge.

Since its beginnings, the syndrome has been presented as a sensible representational object, that is, strongly marked by social norms and moral values, leading to various metaphors associated with the new disease, such as death, horror, crime, punishment, war, shame and pollution ${ }^{(3-4)}$.

AIDS was the first disease entity in which the biomedical, symbolic and social constructions occurred together, highlighting the issue of the relationships established between the process of symbolization and the adoption of daily practices and behaviors. More specifically, in the ambit of social representation theory, between the construction and the social-historical process of transformations of representations in a specific time period and social group, and the social practices adopted in this same group's daily life, in the face of the represented objects( ${ }^{(5-6)}$.

Over the last two decades, the epidemic both around the world and more specifically in Brazil has actively presented epidemiological and social transformations which confer upon it characteristics which are distinct from those seen at the start. From being a city disease, it has gone to being common in rural areas; having originated in the middle and upper classes, it has migrated to the poor; from artistic and cultured circles it has moved to the daily life of ordinary people; and from being restricted to excluded groups - such as homosexuals, sex workers and drug users - it has spread to people who, socially speaking, are not considered vulnerable to the syndrome, such as heterosexuals, monogamic women, older adults and children.

In parallel, the appearance and the dynamism of the evolution of AIDS had repercussions for health institutions and personnel as its presence grew in the everyday of the Brazilian health services, with important implications for public policies and for the constitution of professional care practices.

This study develops the hypothesis of the existence of a precedence of practices determining the formation of representations in the context of AIDS in Brazil, which were shaped by the historical transformations, the development of scientific knowledge and new facts, aiming at new ways of doing and of caring for the ill people and those exposed.

This study's importance lies in the empirical observation of the transformation of the social representations of AIDS and in the inferential analysis of this transformation's consequences for the changing of healthcare practices.

Considering this scenario, this text's objective is to analyze the process of constitution, evolution and transformation of the representations and practices referent to HIV/AIDS among health professionals in Rio de Janeiro.

\section{Method}

This study is the result of a line of investigation in the field of HIV/AIDS, undertaken by a research group, coordinated by the author, since 1999 . The data analyzed was produced in two Master degree dissertations and one multicentric project, all carried out in this context.

Social Representations Theory was adopted(7-8), based on the structural approach or Central Nucleus Theory. This complementary approach considers that the social representation presents a specific characteristic, that of being organized around a central nucleus, being constituted in one or more elements which give significance to the representation, providing the fundamental and inflexible meaning to the same ${ }^{(5)}$. One function attributed to the central nucleus is that of ensuring the representation's permanency, permitting, at this level, the identification of the representational changes. The structural approach's premise is based on the assertion that as the central nucleus is the element which most resists change, any modification of the central nucleus shall lead to a complete transformation of the representation. It is affirmed, therefore, that it is the surveying of this nucleus that permits the comparative study of the representations. For two representations to be different, they must be organized around two different central nuclei(5).

This research was developed based on secondary data from three studies ${ }^{(9-11)}$ carried out in the context of the research group previously cited, based on which the comparison of the representational structures for AIDS identified was made. These studies were produced in the decades of 1990, 2000 and 2010. The choice of the three studies was based on the following criteria: use of similar populations (health professionals); use of identical theoretical guidance and methodology (the structural approach of social representations); and the undertaking of data collection in the decades covered by this text.

The studies analyzed involved 866 professionals, respectively 366 professionals from the health team in Study 1, 150 nurses in Study 2 and 350 professionals 
from the health team in Study 3. They were distributed across 22 research fields located in Rio de Janeiro, these being a university hospital in Study 1, a university hospital in Study 2, and twenty basic health or outpatient units in Study 3.

The methodological proceedings for data collection and analysis (in the studies referred to) were guided by the assumptions of the structural analysis of the social representations, and the technique of free association with the term "HIV/AIDS" was used. The data collection sought to understand the perception of the reality based on a pre-existing semantic composition, this composition being not only concrete but also imagetic, organized around some simple symbolic elements. The practical application of the technique consists of asking the subjects to associate, rapidly and freely, based on hearing or seeing the inductive words (stimuli), other words or expressions ${ }^{(12)}$.

The analyses were done using the EVOC (Ensemble de Programmes Permettant L'Analyse des Évocations) (Group of Programs for the Analysis of Evoked Responses) software, version 2003, which makes it possible to effectuate the organization of the words produced in terms of the hierarchy expressed by the frequency and by the natural order of evocation. The analysis technique consists of constructing a Vergès matrix, in which the words which were evoked are distributed, taking into account the criteria of higher frequencies and considering the average order of evocation (AOE) ${ }^{(13)}$.

In the Vergès matrix, the top left quadrant, termed the central nucleus, included the words which presented the highest frequencies and were evoked the most readily, constituting the most stable and permanent part of a representation, giving it meaning. The lower left quadrant, termed the contrast zone, covers the words which presented lower frequencies but which were also evoked readily, showing variations in the centrality of the representation for specific groups. The two quadrants on the right (upper and lower) involve words which presented lower readiness of evocation and higher or lower frequencies, termed the first and second periphery. The peripheral zone expresses the representational elements associated with the immediate context of life, the daily reality and the social practices, these being therefore unstable, permitting interindividual variability of the representation ${ }^{(12-14)}$.

Experimental studies undertaken in the field of Social Psychology(15-16), indicate the existence of a region which is not made clear - termed the silent zone - in research involving sensitive objects such as AIDS. The studies relate these sensitive objects to the normative pressures present in the social groups, creating a politically correct discourse. Its use in this study aimed to demonstrate that the relationships between practices and representations are not direct, and pass through various modulations, among which is the existence of a silent zone.

The techniques described were extended in one of the studies ${ }^{(10)}$ with the analysis of the representations silent zone, based on the substitution technique, which consists of a methodological strategy for reducing the normative pressures on the subjects' discoursive production, so as to make it possible to express contranormative elements. The application involves requesting the interviewees, after the conventional collection of evocations (normal situation), to respond in the name of another group - in this case, people in general (substitution situation). In this way, the aim is to reduce their involvement in the discourse produced, without compromising their self-presentation in the process of managing impressions and their acceptance in their social groups of origin(15-16). The data was analyzed through the technique of the Vergès matrix, constructed for the normal situation and the substitution situation, with the help of the EVOC software 2003.

All the studies analyzed had been approved by the Ethics Committees involved, ensuring compliance with the Law of Ethics in Research with Human Beings.

\section{Results}

The Vergès matrices obtained in the three studies are presented below. From these, the results observed in the central nuclei of the respective representations for AIDS will be highlighted, as, considering the comparative assumptions, it is at this level that one can identify the representational changes.

One can observe in the results presented in Figure $1^{(9)}$ the prototypic configuration of the constitution of the social representation of AIDS which was characteristic of the 1980's and the start of the 90's. It reflects the symbolic result of construction of the representation of AIDS, characterized by the association "AIDS-death", "AIDS-deviant sexual practices", "AIDS-blood", "AIDSdisease of other" and "AIDS-contagion". These symbolic configurations are expressed in the lexicons: death, fear and disease prevention (present in the central nucleus) and re-affirmed in condom, sex, disease, incurable illness (contrast zone); discrimination, drugs, promiscuity, danger, blood, contamination and shame (peripheral elements). 


\begin{tabular}{|c|c|c|c|c|c|c|}
\hline \multicolumn{7}{|c|}{ Average Order of Evocations } \\
\hline \multicolumn{4}{|c|}{$<2.9$} & \multicolumn{3}{|c|}{$\geq 2.9$} \\
\hline Av. Freq. & $\begin{array}{c}\text { Term evoked } \\
\text { Central Elements }\end{array}$ & Freq. & $\begin{array}{l}\text { Average Order of } \\
\text { Evocations }\end{array}$ & $\begin{array}{l}\text { Term evoked } \\
\text { 1st Periphery }\end{array}$ & Freq. & $\begin{array}{c}\text { Average Order of } \\
\text { Evocations }\end{array}$ \\
\hline$\geq 48$ & $\begin{array}{l}\text { death } \\
\text { suffering } \\
\text { fear } \\
\text { disease prevention }\end{array}$ & $\begin{array}{c}174 \\
116 \\
82 \\
53\end{array}$ & $\begin{array}{l}2.609 \\
2.888 \\
2.793 \\
2.830\end{array}$ & sadness & 59 & 3.051 \\
\hline Av. Freq. & $\begin{array}{c}\text { Term evoked } \\
\text { Contrast Elements }\end{array}$ & Freq. & $\begin{array}{l}\text { Average Order of } \\
\text { Evocations }\end{array}$ & $\begin{array}{l}\text { Term evoked } \\
\text { 2nd Periphery }\end{array}$ & Freq. & $\begin{array}{l}\text { Average Order of } \\
\text { Evocations }\end{array}$ \\
\hline$<48$ & $\begin{array}{l}\text { condom } \\
\text { pain } \\
\text { sex act } \\
\text { disease } \\
\text { incurable illness } \\
\text { depression }\end{array}$ & $\begin{array}{l}47 \\
45 \\
44 \\
36 \\
35 \\
24\end{array}$ & $\begin{array}{l}2.426 \\
2.412 \\
2.432 \\
2.417 \\
2.771 \\
2.875\end{array}$ & $\begin{array}{l}\text { discrimination } \\
\text { drugs } \\
\text { promiscuity } \\
\text { danger } \\
\text { love } \\
\text { solidarity } \\
\text { care } \\
\text { solitude } \\
\text { blood } \\
\text { contamination } \\
\text { shame }\end{array}$ & $\begin{array}{l}41 \\
32 \\
32 \\
30 \\
26 \\
24 \\
23 \\
22 \\
21 \\
20 \\
19\end{array}$ & $\begin{array}{l}3.244 \\
3.156 \\
3.031 \\
3.000 \\
3.231 \\
3.286 \\
2.957 \\
3.409 \\
3.625 \\
3.300 \\
3.474\end{array}$ \\
\hline
\end{tabular}

Figure 1 - Structure of the social representation of AIDS characteristic of the 1980's and beginning of 1990's, among health professionals in a university hospital(9). Rio de Janeiro, Brazil, $2001(n=366)$

The data supports the proposition that, in the absence of medical references, a social qualification of the disease was favored, and that before biological research shed light on the nature of AIDS, people elaborated theories supported in the data which they had available about those affected and the vectors ${ }^{(7)}$.

\begin{tabular}{|c|c|c|c|c|c|c|}
\hline \multicolumn{7}{|c|}{ Average Order of Evocations } \\
\hline \multicolumn{4}{|c|}{$<2.9$} & \multicolumn{3}{|c|}{$\geq 2.9$} \\
\hline Av. Freq. & $\begin{array}{c}\text { Term evoked } \\
\text { Central Elements }\end{array}$ & Freq. & $\begin{array}{l}\text { Average Order of } \\
\text { Evocations }\end{array}$ & $\begin{array}{l}\text { Term evoked } \\
\text { 1st Periphery }\end{array}$ & Freq. & $\begin{array}{c}\text { Average Order of } \\
\text { Evocations }\end{array}$ \\
\hline$\geq 18$ & $\begin{array}{l}\text { Health education } \\
\text { Professional precautions } \\
\text { Treatment }\end{array}$ & $\begin{array}{l}25 \\
20 \\
18\end{array}$ & $\begin{array}{l}2.240 \\
2.700 \\
2.444\end{array}$ & $\begin{array}{l}\text { prejudice } \\
\text { suffering } \\
\text { fear } \\
\text { discrimination } \\
\text { effects of aids }\end{array}$ & $\begin{array}{l}38 \\
31 \\
26 \\
24 \\
24\end{array}$ & $\begin{array}{l}3.053 \\
3.000 \\
3.962 \\
3.042 \\
3.542\end{array}$ \\
\hline Av. Freq. & $\begin{array}{c}\text { Term evoked } \\
\text { Contrast elements }\end{array}$ & Freq. & $\begin{array}{l}\text { Average Order of } \\
\text { Evocations }\end{array}$ & $\begin{array}{l}\text { Term evoked } \\
\text { 2nd Periphery }\end{array}$ & Freq. & $\begin{array}{c}\text { Average Order of } \\
\text { Evocations }\end{array}$ \\
\hline$<18$ & $\begin{array}{l}\text { family } \\
\text { hope } \\
\text { help } \\
\text { medication } \\
\text { solidarity } \\
\text { disease control } \\
\text { disease prevention }\end{array}$ & $\begin{array}{l}17 \\
16 \\
15 \\
14 \\
13 \\
12 \\
11\end{array}$ & $\begin{array}{l}2.706 \\
2.688 \\
2.733 \\
2.571 \\
2.769 \\
2.833 \\
2.182 \\
\end{array}$ & $\begin{array}{l}\text { death } \\
\text { sadness } \\
\text { disease } \\
\text { tenderness }\end{array}$ & $\begin{array}{l}14 \\
13 \\
13 \\
11\end{array}$ & $\begin{array}{l}3.500 \\
2.923 \\
3.846 \\
3.000\end{array}$ \\
\hline
\end{tabular}

Figure 2 - Structure of the social representation of AIDS in the 1990's and beginning of 2000, among nurses in a university hospital - normal situation of collection(10). Rio de Janeiro, Brazil, $2001(n=150)$ 
In the results of the study presented in Figure $2^{(10)}$ one can observe the prototypic configuration of the social representation of AIDS in the 1990's and beginning of 2000 , in the normal situation of data collection. It reflects the first movement of change in the representation of AIDS reflected in the Central Nucleus zone, characterized by the development of steps for confronting the disease (health education and treatment), but also by the identification of the need for prevention of professional contagion (professional precaution). These symbolic constructions are re-affirmed in the contrast zone by the elements medications, disease control and disease prevention. The maintenance of meanings constructed in the previous decade is shown by the lexicons prejudice, fear, discrimination and effects of AIDS in the first periphery, and by the components death and disease in the second periphery.

The implantation of public policies and the reorientation of the health services for attending people affected by this condition determined new professional practices characterized by the selective use of personal protection techniques and by greater closeness of the interpersonal relationship in carrying out care practices, observed in the lexicons health education, professional precautions and treatment, present in the central nucleus. Taking into account the assumptions of the structural approach, a central nucleus with a more functional aspect was observed, directed at confronting the disease rather than submitting to it as previously, conferring meaning and organization on the other cognitions of the representation studied.

This representation is characterized as the result of the change in the disease's epidemiological profile, with the appearance of the syndrome among women and children, determining a first change in the meanings associated with AIDS. This process of change was involved in the transposition of the meaning "disease of other" to "disease of my group", and identification of gender among nurses and women. Further, the decade of the 90's was characterized by universal access to anti-retroviral drugs (ARVs), determining the increased survival of patients and creating, on the symbolic level, the transformation of the representations with the shift of the meaning "AIDS-death" to the periphery.

\begin{tabular}{|c|c|c|c|c|c|c|}
\hline \multicolumn{7}{|c|}{ Average Order of Evocations } \\
\hline \multicolumn{4}{|c|}{$<2.9$} & \multicolumn{3}{|c|}{$\geq 2.9$} \\
\hline \multirow{2}{*}{ Av. Freq. } & Term evoked & \multirow{2}{*}{ Freq. } & \multirow{2}{*}{$\begin{array}{l}\text { Average Order of } \\
\text { Evocations }\end{array}$} & Term evoked & \multirow{2}{*}{ Freq. } & \multirow{2}{*}{$\begin{array}{l}\text { Average Order of } \\
\text { Evocations }\end{array}$} \\
\hline & Central Elements & & & 1st Periphery & & \\
\hline \multirow[t]{3}{*}{$\geq 28$} & fear & 83 & 2.048 & pity & 46 & 3.435 \\
\hline & prejudice & 61 & 2.148 & death & 41 & 3.195 \\
\hline & homosexuality & 30 & 2.400 & discrimination & 28 & 3.679 \\
\hline \multirow{2}{*}{ Av. Freq. } & Term evoked & \multirow{2}{*}{ Freq. } & \multirow{2}{*}{ AOE } & Term evoked & \multirow{2}{*}{ Freq. } & \multirow{2}{*}{ AOE } \\
\hline & Contrast Elements & & & 2nd Periphery & & \\
\hline \multirow[t]{7}{*}{$<28$} & contamination & 25 & 2.480 & promiscuity & 27 & 3.148 \\
\hline & disease & 18 & 2.833 & distancing & 24 & 3.417 \\
\hline & sexual practice & 17 & 2.824 & misinformation & 21 & 2.905 \\
\hline & contagion & 11 & 1.909 & isolation & 17 & 3.294 \\
\hline & & & & use of drugs & 15 & 3.600 \\
\hline & & & & rejection & 14 & 3.286 \\
\hline & & & & suffering & 13 & 4.231 \\
\hline
\end{tabular}

Figure 3 - Structure of the social representation of AIDS, characteristic of the 90's and the beginning of 2000, among nurses in a university hospital - substitution situation ${ }^{(10)}$. Rio de Janeiro, Brazil, $2001 \quad(n=150)$

In the results of the study presented in Figure $3^{(10)}$, one can observe the configuration of the social representation of AIDS in the substitution situation, as a demonstration of the elements characterizing the existence of a silent zone. The central nucleus of the Vergès matrix, constructed either for the contranormative situation or for the substitution situation, was composed of elements more related to moral judgments, pointing to cognitions which were negative and affectively highlighted in the representation of AIDS.

On comparing the lexicons present in the two central nuclei, in the normal situation and in the substitution situation, it may be observed that the first representation is structured by positive elements associated with actions for confronting HIV and AIDS, expressed in treatment, professional precautions, 
and health education. In the second, however, the structuring elements are negative, associated with the threat of destruction, social isolation, and the causes or "guilty" for the transmission of HIV, expressed by fear, prejudice, and homosexuality. The position of the element death also varies in this comparison, shifting from the second to the first periphery, taking on a more emphasized role in the substitution situation.
During the decade of 2000, based on the representational changes observed between the decades of the 1980's and 1990's, the constitution of an unexplained zone was observed in the social representation of AIDS, with the strengthening of a politically correct discourse and the maintenance of discursive masking, as demonstrated in Figures 2 and 3.

\begin{tabular}{|c|c|c|c|c|c|c|}
\hline \multicolumn{7}{|c|}{ Average Order of Evocations } \\
\hline \multicolumn{4}{|c|}{$<2.9$} & \multicolumn{3}{|c|}{$\geq 2.9$} \\
\hline Av. Freq. & $\begin{array}{c}\text { Term evoked } \\
\text { Central Elements }\end{array}$ & Freq. & $\begin{array}{l}\text { Average Order of } \\
\text { Evocations }\end{array}$ & $\begin{array}{l}\text { Term evoked } \\
\text { 1st Periphery }\end{array}$ & Freq. & $\begin{array}{l}\text { Average Order of } \\
\text { Evocations }\end{array}$ \\
\hline$\geq 44$ & $\begin{array}{l}\text { prejudice } \\
\text { treatment } \\
\text { disease prevention } \\
\text { fear } \\
\text { care } \\
\text { disease }\end{array}$ & $\begin{array}{l}144 \\
89 \\
74 \\
55 \\
53 \\
44\end{array}$ & $\begin{array}{l}2.403 \\
2.820 \\
2.514 \\
2.764 \\
2.203 \\
2.159 \\
\end{array}$ & Compliance with treatment & 44 & 2.932 \\
\hline Av. Freq. & $\begin{array}{c}\text { Term evoked } \\
\text { Contrast Elements }\end{array}$ & Freq. & $\begin{array}{l}\text { Average Order of } \\
\text { Evocations }\end{array}$ & $\begin{array}{l}\text { Term evoked } \\
\text { 2nd. Periphery }\end{array}$ & Freq. & $\begin{array}{l}\text { Average Order of } \\
\text { Evocations }\end{array}$ \\
\hline$<44$ & $\begin{array}{l}\text { suffering } \\
\text { sadness }\end{array}$ & $\begin{array}{l}36 \\
31\end{array}$ & $\begin{array}{l}2.056 \\
2.871\end{array}$ & $\begin{array}{l}\text { death } \\
\text { help } \\
\text { medication } \\
\text { rebirth } \\
\text { condom } \\
\text { knowledge } \\
\text { counseling } \\
\text { hope } \\
\text { fight }\end{array}$ & $\begin{array}{l}41 \\
33 \\
32 \\
26 \\
23 \\
21 \\
19 \\
18 \\
18\end{array}$ & $\begin{array}{l}2.902 \\
2.970 \\
3.094 \\
3.808 \\
3.435 \\
3.524 \\
3.000 \\
3.500 \\
3.111\end{array}$ \\
\hline
\end{tabular}

Figure 4 - Structure of the social representation of AIDS, characteristic of the second half of the decade of 2000 and the beginning of 2010 among health professionals in twenty health institutions ${ }^{(11)}$. Rio de Janeiro, Brazil, 2001 ( $n=350$ )

One can observe in Figure $3^{(11)}$ the prototypic configuration of the social representation of AIDS in the second half of the decade after 2000 and the beginning of 2010. This representation is characterized by the construction of "AIDS as a chronic disease", changing to include - in the central nucleus - positive meanings and normative elements for confronting the disease (treatment, disease prevention, and care). This symbolic content is re-affirmed in the peripheral system, by the lexicons: compliance with treatment, help, medications, condom, knowledge, and counseling. The consolidated shift of the symbolization "AIDS-death" to the second periphery of representation also stands out, with the gradual incorporation of elements referring to survival, such as re-birth, hope and fight.

The period was marked by the centrality of the antiretroviral drugs in confronting the disease, ensuring the survival of the affected persons, present in the lexicon treatment, and re-affirmed in compliance with treatment and medications. It was also marked by the appearance of undesirable effects associated with the prolonged use of the drugs, determining negative elements in the representation's contrast zone (suffering and sadness).

This historic moment of symbolic construction of AIDS is still manifested through the permanency of the lexicons prejudice and fear as meanings incorporated into the central nucleus since the first days of the disease's psychosocial constitution, appearing as a distinctive feature and one of the permanent elements of the original representation.

\section{Discussion}

The analysis presented demonstrates the presence of a process of representational change in two senses. Firstly, one can observe a circular process of change, referring to the mobilization of symbolic elements from 
the central nucleus in the direction of the representation's periphery, with the gradual exclusion of elements no longer shared by the social group. Secondly, there is movement of the contrast elements towards the central nucleus, incorporating the representation's interindividual variability into socially-shared thinking.

This representational change in the group of health professionals is characterized by the transition of negative meanings to positive ones associated with AIDS, with the introduction of the possibility of coexisting with the disease, and the reduction in the importance of death, associated with the existence of a specific normative system. On the other hand, the possible existence of cognitive elements which remain unchanged was evidenced, which were expressed in the elements in the silent zone of the representations studied. This analysis demonstrated the linking of AIDS to homosexual practices, to drug use and to death, as well as to attitudes of prejudice and to the feeling of fear, with impacts on professional practice in health.

The representational profile characterized by death and by fear was associated, in the decades of the 1980's and 1990's, with professional care practices characterized by the imposition of physical distancing and the use of exaggerated techniques for professional self-protection and also by psychosocial distancing, observed in the interpersonal relationships with the patients during the carrying-out of care practices. The relationships established between practices and representations, at this point of the syndrome's development, were characterized by a process of precedence of professional practices determining the ways of thinking about AIDS. The representations were constituted and shaped by the disease's concrete characteristics and the self-protection practices imposed by the lack of scientific knowledge, by the high mortality observed, and by the fear of contamination.

One can emphasize the anchoring of these practices in social memories of the great epidemics of the infectiouscontagious diseases, faced by Western society at different points in its history. The Black Death, The Spanish Flu, Syphilis and Cholera, for example, seem to have supported these practices, endowing them with prudence, in the face of an unknown morbid entity. Simultaneously, one should note the presence of the North American modus operandi in the initial approach to the syndrome, characterized by complete isolation and by quarantine, both as a cultural/ symbolical factor associated with the technology, and as due to the first cases having been described in the United States of America.
Considering the continuity of the symbolical construction of AIDS in the nineties and the beginning of 2000 , in the area of relationships between practices and representations, the maintenance of the precedence of professional practices determining AIDS' representations was observed, now more structured. This type of relationship conditioned a process of progressive transformation of the representation ${ }^{(5)}$, which was gradually shaped by new scientific discoveries and new ways of caring in health. This gradual change had as its substrate the permanent elements observed in the silent zone, still strongly marked by death and by the exclusion of persons struck by the virus.

One important element in the process of representational change and the relationships between practices and representations was the incorporation of anti-retroviral therapy in association with prevention (present in the representation from the beginning of the epidemic), as technologies for confronting AIDS. It may be noticed that this process establishes relationships with the knowledge of the technologies available for treatment and for professional care, ensuring life and strengthening the feeling of protection in the professionals $^{(17)}$.

In a study made with nurses caring for people with HIV/AIDS ${ }^{(18)}$, a relationship was verified between the care given and the representation of the patients as victims or as guilty for the contamination. In the first group - of subjects represented as victims - the care given was described as equal to that given to other patients, whereas the second group - those blamed for the contamination of others - were discretely isolated and maintained at a distance from the health professionals. This cognitive process of classification and judgment is typical of a process of management of impressions and social desirability, which may be defined as an accessible dictionary on which the groups can support themselves when necessary - which applies, particularly, to situations involving expression of prejudice in society ${ }^{(19)}$.

In the second half of the first decade of the new millennium and in the beginning of 2010, one can observe a change in the process of determination of the relationships between thought and action. The representations increasingly determine the social and professional practices, as the ways of caring in health were shaped by the new psychosocial content of AIDS and people with AIDS, now more structured.

Concerning health practices, the representations took on an important dimension, as they made it possible to understand the processes and mechanisms through 
which the meaning of the work object is constructed by the health professionals in their daily relationships. This is because when one wishes to transform health practices, it is necessary to think about them as expressed objectively and subjectively, as the health intervention strategies are put into action by people, who act according to their representations of the real and their representations of the possible(20).

The process involved in pharmacological treatment and the directives of the Brazilian National HIV/AIDS Program currently have a strong influence on the representations and on professional practice. As a result of this, the positivity made clear by the allusion to life and hope is found in parallel with negativity, especially expressed by fear and prejudice. One can observe a process of naturalization of the syndrome, in the set of chronic illnesses, as a result of its recent anchoring in pathologies such as diabetes mellitus and hypertension, instead of with cancer and plague, as initially ${ }^{(21-22)}$. On one hand, this process is associated with the technological characteristics attributed to drug treatment, and to the patients' constant dependency on the health services and staff, and on the other with the work of the media in giving visibility to the survival of the subjects at the present time.

Finally, one must not forget that at the present time the continuity of the elements of a silent zone in the representation of AIDS may be considered as an element which influences health care practices. In everyday professional activities, two central cognitions act, tensioning practices, principally in their relational aspect: on the one side, the classifications as victim or guilty, right and wrong, and on the other, the notions of chronic illness and equality of care. These cognitions are contradictory, and - as such - imprint a specific characteristic on care practices, which is to be ambivalent and determined, to a large extent, by personal values and by the need perceived for personal protection measures at work ${ }^{(17)}$.

\section{Conclusions}

The study demonstrates the existence of a process of change being operated in the social representations for AIDS, as a result of the introduction of the possibility of co-existence with the disease and the reduction of the importance of death. This process of change has been demonstrated empirically in this text, through the analysis of representational structures, contributing to what is known about the issue of the ways of thinking associated with HIV and AIDS, as well as of the relationships established between representations and professional practices.

The existence of meaningful symbolic elements which remain unchanged over time was evidenced, objectifying AIDS in homosexuality, in prejudice, in drug abuse, in fear and in death, which made up the elements of the silent zone of the social representations studied.

The vital importance of social representations for the professional addressing of HIV/AIDS was also observed, as this makes it possible to understand the processes and mechanisms by which the social meaning of the object is constructed by the subjects in their everyday relationships, forming the symbolic base on which the health care practices rest.

The process of transforming the health professionals' social representations in relation to the condition in question has permitted the development of a practical expertise which adheres to the values, norms, beliefs and memories shared by the groups, but also to the scientific knowledge, which is incorporated by these agents into the constitution of a particular way of symbolizing, that is, the socio-professional representations.

\section{References}

1. Center for Diseases Control and Prevention. Follow up on kaposi sarcoma and pneumocycstis pneumonia. Morbidity and Mortality Weekly Report. 1981;30:409-10. 2. Nascimento DR. As pestes do século $X X$ : tuberculose e aids no Brasil. Rio de Janeiro: Fiocruz; 2005. 196 p.

3. Sontag S. Doença como metáfora, aids e suas metáforas. São Paulo: Companhia das Letras; 2007. $168 \mathrm{p}$.

4. Malcolm A, Aggleton P, Bronfman M, Galvão J, Mane $P$, Verrall J. HIV and aids-related stigmatization: its form and contexts. Critical Public Health. 1998;8(4):347-70.

5. Abric JC. Pratiques sociales et représentations. Paris: Presses Universitaires de France; 1994. 251 p.

6. Oliveira DC. A teoria de representações sociais como grade de leitura da saúde e da doença: a constituição de um campo interdisciplinar. In: Almeida AMO, Santos MFS, Trindade ZA. Teoria das representações sociais 50 Anos. Brasília: Technopolitik; 2011. p. 585-624.

7. Jodelet D. Représentations sociales: un domaine en expansion. In: Jodelet D. Les représentations sociales. Paris: Presses Universitaires de France; 1989. p. 17-44. 8. Moscovici S. La psychanalyse, son image et son public. Paris: Presses Universitaires de France; 1976. 509 p.

9. Marques SC, Oliveira DC, Francisco MTR. Abordagem 
estrutural das representações sociais da aids entre os servidores de um hospital universitário. Esc. Anna Nery. 2004;7(2):186-195.

10. Costa TL, Oliveira DC. A zona muda das representações sociais sobre o portador de HIV/ aids: elementos normativos e contra-normativos do pensamento social. Psicol. Teor. Prat. 2007;9(2):73-91. 11. Oliveira DC, Apostolidis T, Gomes AMT. Construção e transformação de representações sociais e práticas no contexto da aids em dois contextos socio-culturais: Brasil e França [resumo]. In: Jesuíno JC, Lopes MJ, Mendes F, Silva AO, organizadores. Resumos da $11^{a}$ Conferência Internacional de Representações Sociais; 2012 25-29 julho; Évora, Portugal. Évora: Universidade de Évora; 2012. p. 1-4.

12. Oliveira DC, Gomes AMT, Marques SC. Análise das evocações livres: uma técnica de análise estrutural das representações sociais. In: Paredes AS. Perspectivas Teórico-Metodológicas em representações sociais. João Pessoa: Editora Universitária UFPB; 2005. p. 573-603.

13. Dany L, Abric JC. Distance à I'objet et représentations du cannabis. International Review of Social Psychology. 2007;20:77-104.

14. Sá CP. Núcleo central das representações sociais. Petrópolis: Vozes; 1996. 189 p.

15. Abric JC. La recherche du noyau central et la zone muette des représentations sociales. In: Abric JC. Méthodes d'études des représentations sociales. Ramonville Saint-Agne: Éditions Ères; 2003. p. 60-80.

16. Flament C, Guimelli C, Abric JC. Effets de masquage dans l'expression d'une representation sociale. Les Cahiers Internationaux de Psychologie Sociale. 2006;69(1):15-31.

17. Souza MCMR, Freitas MIF. Representations of primary care professionals about the occupational risk of HIV infection. Rev. Latino-Am. Enfermagem. 2010;18(4):748-54.

18. Formozo GA, Oliveira DC. Representações sociais do cuidado prestado aos pacientes soropositivos ao HIV. Revista Brasileira de Enfermagem. 2010;63:230-37.

19. Apostolidis T, Dany L. Représentations sociales et risques sanitaires: perspectives sociocognitives. Revista Tempus Actas de Saúde Coletiva. 2012;6(3):35:50.

20. Oliveira DC, Gomes AMT. Construção de um paradigma de cuidado de enfermagem pautado nas necessidades humanas e de saúde. Escola Anna Nery. 2011;15:838-844.

21. Gomes AMT. A vulnerabilidade como elemento organizador do cuidado de enfermagem no contexto do HIV/aids: conceitos, processos e representações sociais [tese de professor titular]. Rio de Janeiro (RJ) Faculdade de Enfermagem da Universidade do Estado do Rio de Janeiro; 2011. 414 p.

22. Gomes AMT, Silva EMP, Oliveira DC. Social representations of aids and their quotidian interfaces for people living with HIV. Rev. Latino-Am. Enfermagem. 2011;19(3):485-92. 
